\title{
An Approach to Study the Poverty Reduction Effect of Digital Inclusive Finance from a Multidimensional Perspective Based on Clustering Algorithms
}

\author{
Lu Zhou $\mathbb{D i D}^{1,2}$ and Huiling Wang $\mathbb{D}^{3}$ \\ ${ }^{1}$ College of Finance, Tianjin University of Finance and Economics, Tianjin 300222, China \\ ${ }^{2}$ Tianjin Renai College, Tianjin 301636, China \\ ${ }^{3}$ Chongqing City Management College, Chongqing 401331, China
}

Correspondence should be addressed to Huiling Wang; 289672983@qq.com

Received 10 August 2021; Revised 7 September 2021; Accepted 21 September 2021; Published 29 September 2021

Academic Editor: Punit Gupta

Copyright ( 2021 Lu Zhou and Huiling Wang. This is an open access article distributed under the Creative Commons Attribution License, which permits unrestricted use, distribution, and reproduction in any medium, provided the original work is properly cited.

\begin{abstract}
The evaluation of clustering algorithms is intrinsically difficult because of the lack of objective measures. On the basis of the DIFI and China's Provincial Panel data, this study aims to test the poverty reduction effect of digital inclusive finance in three dimensions of income, education, and healthcare and further look at the transmission mechanism of digital inclusive finance in poverty alleviation. The results indicated that digital inclusive finance exerts a poverty reduction effect in three dimensions-medical poverty, income poverty, and education poverty. Of these, the coverage breadth significantly affects the alleviation of medical poverty, the use depth significantly affects the alleviation of income poverty and education poverty, and the digitization level affects the alleviation of poverty in three dimensions. The level of regional economic development plays an intermediary role in the poverty alleviation effect of digital inclusive finance. Compared with the western region, which is relatively backward in development, the poverty reduction effect of digital inclusive finance in the eastern region is more significant.
\end{abstract}

\section{Introduction}

Poverty alleviation has been placed in the important position of governing the country in China, and poverty eradication has become one of the fundamental tasks of building a moderately prosperous society in 2020 . Over the past 40 years, people's living standards have continuously improved, and poverty alleviation has also attained remarkable results. When counting the number of poor people from 2015 to 2019, the score dropped from 55.75 million to 5.51 million, while poverty declined from $5.7 \%$ to $0.6 \%$. Nevertheless, the work on poverty reduction in deep poverty-stricken areas still faces significant challenges. Per the endogenous growth theory, it is challenging for impoverished areas to get out of poverty because of the lack of funds and talents, which lead to economic activities producing low benefits. Financial support is an essential factor in poverty alleviation, and financial exclusion is predominantly evident in rural areas. Serious financing constraints have become a vital factor affecting poverty alleviation. The government work report in 2018 emphasized "supporting financial institutions to expand the inclusive financial business and increase efforts to get rid of poverty precisely." In 2019, the People's Bank of China issued guidance on carrying out a job effectively in financial targeted poverty alleviation from 2019 to 2020 . In addition, it put forth specific requirements on optimizing the allocation of financial resources, innovating financial products and services, and enhancing the financial support for targeted poverty alleviation. Of note, alleviation of financial poverty plays a crucial role in targeted poverty alleviation. By constructing the financial system, financial services can be supplied for vulnerable groups and attain inclusive economic growth. 
Owing to the limitation of the region or economic status, the poor groups have been unable to obtain sufficient financial services and have been in financial exclusion for a long time. Inclusive finance entails providing financial services to the excluded vulnerable groups and poor groups at an affordable cost, thereby ensuring that all social strata, including vulnerable and marginalized groups, can equally obtain the opportunities and it eventually benefits all people. With the improvement of financial inclusiveness, on the one hand, low-income groups will have access to financial services such that their consumption can be more stable and their production activities can be executed smoothly. Besides, insurance services can provide corresponding protection for them, decrease the risk of adverse impact, and thereby attain poverty alleviation. On the other hand, providing apposite financial services for low-income groups can promote an increase in their income and decrease the degree of income inequality.

Before the emergence of digital inclusive finance (DIF), customers could only handle business in the physical outlets of financial institutions. Owing to the limitation of geographical location or the level of economic development, financial institutions in poor areas set up very few outlets, and the financial products and services that residents could access were also minimal. To understand inclusive finance, that is, to increase financial availability, it is essential to enlarge the coverage of financial services. Under the traditional business model, the expansion of coverage certainly warrants the expansion of financial institutions' outlets, which requires considerable capital investment, which undoubtedly increases the operating cost of financial institutions, which would eventually be transformed into financial services. Although the expansion of financial institutions has accomplished geographical coverage, the enormous cost can completely offset the benefits of regional coverage. Digital inclusive finance can resolve this contradiction and decrease the increase in cost caused by the expansion of financial institutions' physical outlets to some extent and fill the gap in financial infrastructure. Digital inclusive finance overcomes the limitation of geographical location, shortens the distance between residents in poverty-stricken areas and finance, and improves access to financial services that were not available before. With the progress of information and communication technology, the internet penetration rate in China has been increasing year by year. It is estimated that the penetration rate of internet will reach $70.4 \%$ by the end of 2020 , and the scale of mobile internet users will reach 989 million. Internet and smartphones have become an indispensable part of people's lives, and their high popularity strongly supports the development of digital inclusive finance. People can handle most of their financial businesses through the use of the internet and smartphones, which also provides the opportunity for the groups who are unable or inconvenient to handle financial business in the physical outlets of financial institutions to enjoy financial products and services. Speaking on a comparative basis, digital inclusive finance has the characteristics of a relatively lower operating cost and wide coverage, which means it can provide low-income groups with lower-cost financial products and services.
The blood transfusion poverty alleviation model is just like drinking poison to quench thirst; it can alleviate poverty in a short period, but is not conducive to the sustainable development of the region. Does the digital inclusive finance with wide coverage, fast information transmission, and low transaction cost support the regional economic growth? Has poverty alleviation been promoted? This study discusses and examines these problems.

\section{Literature Review and Research Hypothesis}

2.1. Literature Review. When the United Nations designated 2005 as the "International Year of Microcredit," it formally proposed the concept of inclusive finance, which aims to promote microcredit services, augment financial inclusiveness, and provide suitable financial services for the poor and vulnerable groups, which will help improve the status quo of the poor and vulnerable groups who have been in financial exclusion for a long time that will help alleviate and eventually eliminate poverty.

The demand for financial services of vulnerable groups cannot be met and also cannot match the financial services provided by financial institutions, which makes some groups and individuals incapable of entering the formal financial system [1] and acquire safe, appropriate, fair, and low-cost financial products and services from formal financial institutions [2]. To alter the status quo of financial exclusion, we need to promote the growth of inclusive finance. Inclusive finance can ensure that all groups can easily enjoy formal financial services [3] and also that the vulnerable groups have access to financial services and acquire adequate credit timely at an affordable cost [4]. Regarding the standards and methods of inclusive finance measurement, Honohan [5] developed a measurement index based on the proportion of access of the adult population to formal financial services [6] and created a comprehensive index to measure inclusive finance from multiple dimensions. Most scholars systematically created the inclusive finance index system from the aspects of geographical penetration, availability, and utility of financial services that will reflect the development level of inclusive finance.

With the proposal of the concept of "inclusive finance" and the expansion of inclusive finance practice, many scholars explored the economic impact of inclusive finance. Inclusive finance has a certain positive effect on finance stability. During the whole financial crisis, poor depositors and borrowers tended to maintain moderate financial behavior, pay off their loans on time, and deposit their deposits in a safe place [7]. Brune et al. [8] investigated the correlation between the expansion of bank branches and poverty reduction in India and reported that the expansion of rural bank branches helped cut down poverty, especially in rural areas without banks, and the decline in the poverty rate was more prominent. Beck et al. [9] claimed that, in the developed financial system, the income of the low-income group increases faster, the Gini coefficient declines faster, the proportion of the poor population decreases faster, and the cash flow constraints of enterprises are easier to resolve. Demirgüç-Kunt and Levine [10] deemed that financial 
development could promote economic activities, stimulate the labor demand, increase income, and provide more prosperous economic opportunities. In comparison to the higher-income groups and large companies, financial development exerted a greater positive impact on low-income groups, low-income families, and small enterprises. Allen et al. [11] found that the increase in commercial bank penetration positively and significantly affected the use of bank accounts and bank credit by Kenyan households, especially for families with no income or low income, and low education level. The increase in banking activities, especially the penetration of the microfinance business, would affect poverty and income inequality. Alvarez de la Campa [12] demonstrated that it is hard for the poor to accumulate savings to pay for health and education, and the lack of financing channels has gravely restricted the economic growth and poverty alleviation in the Middle East and North Africa. Pearce [13] highlighted that, despite the expansion of bank branches and microfinance institutions in some Middle East and North African countries, a large part of the population still has no access to financial services. Emara and Mohieldin [14] suggested that when people are included in the financial system, they could better improve their health, invest in education and business, and make choices beneficial to their entire family.

In addition, the crucial role of the development of information technology has been recognized in inclusive finance. Andrianaivo and Kpodar [15] utilized African countries as samples to explore the impact of ICT, especially the emergence of mobile phones, on economic growth. The research demonstrated that the growth of ICT, including mobile phones, promoted the development of inclusive finance and consolidated the impact on economic growth. The M-PESA system, designed and put to use in Kenya, allows money to flow electronically, thus letting the money flow to penetrate rural areas, thereby increasing income inflows for many rural residents. The G20 advanced principles of digital inclusive finance were proposed in 2016, which aimed to promote the growth of DIF, provided services for those who did not enjoy enough financial services, and resolved the "last mile" problem of financial services. Klapper et al. [16] claimed that digital payment-whether its healthcare, education, or other social safety nets-has crucial benefits for individuals. Moreover, it can enhance the efficiency of the government and aid agencies by decreasing transaction costs and leakage. Beck et al. [17] illustrated that the availability of mobile currency reduced the incidence of theft, thereby decreasing the output loss; however, it also alleviated the transaction friction between enterprises and suppliers, improved the value of trade credit, and had a positive impact on the growth of enterprises.

2.2. Research Hypothesis. The development of DIF decreases the degree of financial exclusion, provides various financial services, such as savings, insurance, credit, and payment, for the poor, expands the availability and payment convenience of financial services for the low-income groups, and enhances the ability of poor groups to resist risks. Poor groups are unable to get sufficient funds to support their labor production and venture capital in the environment of financial exclusion, which also bounds consumption growth [18]. In remote areas with poor conditions, there is generally a lack of financial institutions; this makes it hard for people in these areas to enjoy financial services. Digital inclusive finance overcomes the limitation of geographical conditions, provides convenient information transmission and financial transaction platform for the capital supplier and demander, breaks the barrier of financial exclusion, provides the poor groups with the funds needed for production and life, fulfills the investment needs of some poor groups, stimulates the innovation and entrepreneurship vitality of reform groups, and promotes the growth of the local economy. With the improvement in economic development, the employment situation and the level of income of the poor groups will be improved, which would drive the local consumption, and the improvement in the level of consumption would further drive the economic growth. In addition, low antirisk ability is a major feature of poor groups. Digital inclusive finance enhances the ability of poor groups to resist risks through credit, insurance, and other financial services. When poor groups fall into various unexpected challenging situations, such as diseases and disasters, the services offered by digital inclusive finance can help poor groups come out of such situations.

Digital inclusive finance not only overcomes geographical limitations but also decreases the cost of financial services. In China's poverty-stricken areas, with the continuous development of communication infrastructure, the application scope of digital technology continues to expand, which provides technical support for poverty-stricken areas to decrease the cost of various financial services and enjoy appropriate services. For one thing, it decreases the threshold of financial services by taking advantage of the wide coverage of the internet, as well as decreases the cost of construction and operation of financial institutions by combining face recognition, identity authentication, and other technologies. For another, the application of big data, cloud computing, and other technologies in the financial field accelerates information transmission and decreases market information asymmetry. Financial institutions can offer more accurate financial services for the poor, resolve the problem of financial mismatch to some extent, and enhance the efficiency of resource allocation. The establishment and improvement of the credit reference system improve the impact of risk control on financial institutions and decrease the cost of risk control. Moreover, DIF increases the transparency of information, intensifies the competition between financial institutions, promotes the reform of financial institutions, and is conducive to the innovation of financial products and the improvement of the service level. Furthermore, digital inclusive finance not only provides financial services to poor groups but also provides people with a channel to understand finance, which contributes to the improvement of financial literacy of poor groups.

The digital inclusive finance makes the poor people, who are separated from finance, avail the opportunity to enjoy 
the appropriate financial products and services. The poor areas can obtain low-cost credit funds, provide financial support for the industrial development of the poor areas, advance the economic growth of the area, and eventually abolish poverty. In addition, digital inclusive finance can facilitate more people to enjoy financial services, especially in remote rural areas, accumulate funds through savings and invest in poor areas, promote economic growth, create more employment opportunities, and improve the income level of people in poor areas. The increase in the level of income among people will lead to an increase in consumption, which will further promote the expansion of the local economy. The sustained economic growth not only increases people's income but also increases the education funds in the region, as well as provides student loans for poor families, thus helping to improve the education level of the children of poor families and amplifying their employment opportunities and work income. Likewise, sustained economic growth can increase medical and health expenditure, increase the investment in medical institutions and medical funds, and alleviate the medical poverty in the region. Furthermore, poor groups can use mobile terminals and internet platforms to choose the appropriate insurance or crowdfunding and other mutual aid ways to resist risks and alleviate medical poverty.

Accordingly, the following research hypotheses are proposed:

H1: the level of DIF is conducive to the alleviation of income poverty

$\mathrm{H} 2$ : the level of DIF is conducive to alleviating educational poverty

H3: the level of DIF is conducive to the alleviation of medical poverty

\section{Materials and Methods}

3.1. Sample Selection and Data Sources. The DIF index is published by the Digital Finance Research Center of Peking University [19]. Since 2001, the Digital Finance Research Center of Peking University and Ant Financial Group have estimated the DIF index every year. Ant Financial Group provides inclusive financial services to the world. Based on the hundreds of millions of transaction account, DIF index reflects the overall development and trend of digital finance [20]. Other data were obtained from China's economic and social development $(\mathrm{C} / \mathrm{E} / \mathrm{S} / \mathrm{D})$ database, and other indicators were calculated through source data. The DIFI covered the period from 2011 to 2018; therefore, the selected samples were from 2011 to 2018.

\subsection{Model Specifications and Variable Selection}

3.2.1. Model Specifications. To validate hypotheses H1, H2, and H3, we employ fixed-effect models to examine the DIF effects on poverty reduction. Let $\mathrm{POV}_{i, t}$ indicate poverty indicators for province $i$ in year $t$. The detailed model specifications are given as follows:

$$
\mathrm{POV}_{i, t}=\beta_{0}+\beta_{1} \mathrm{DIFI}_{i, t}+\delta_{i}+\theta_{t}+\varepsilon_{i, t},
$$

where $\mathrm{DIFI}_{i, t}$ denotes the overall DIF index for province $i$ in year $t$. For the estimations, we control for the fixed effects of the province and year, $\delta_{i}$ and $\theta_{t}$ in equation (1).

3.2.2. Variable Selection. The explained variable POV denotes income poverty, education poverty, and medical poverty, respectively, and is reflected by rural per capita disposable income, average number of junior high school students per 1,00,000 population, and diagnosis and treatment rate of township hospitals. The explanatory variable DIFI denotes the digital inclusive finance index. Based on the existing literature, income gap (THEIL), degree of opening up (IE), financial expenditure (FE), urbanization (UR), and inflation rate (CPI) were selected as control variables. This study further controlled the provincial fixed effect and year fixed effect. $\varepsilon$ represents the random error. Table 1 shows the main variables and their definitions selected in this study.

\subsection{Results and Analysis}

3.3.1. Descriptive Statistical Analysis. The descriptive statistical results of the sample are shown in Table 2. The average values of POV1, POV2, and POV3 were 11,334.090, 3309.706, and 436.829, respectively, and their standard deviations were 4729.642, 936.138, and 151.169, respectively. The distributions of other variables were in a reasonable range.

3.3.2. The Impact of DIF on Poverty Alleviation. This study regressed the model and tested the impact of DIF on poverty alleviation. In order to ensure the robustness of the estimation results, the clustering robust standard error was used. Table 3 shows the specific results; columns (1) and (2) take income poverty (POV1) as the dependent variable, and column (1) only adds the independent variable digital inclusive finance index (DIFI) for regression, with the coefficient of 61.359 that is significant at the $1 \%$ level. This reveals that the higher the DIFI, the higher the per capita disposable income of farmers in this region, which alleviates the income poverty. Based on column (1), column (2) further adds other factors that affect poverty alleviation. The coefficient of the DIFI decreases to 50.467 , but it is still significant at the $1 \%$ level. Columns (3) and (4) take education poverty (POV2) as the dependent variable, and column (1) only adds the independent variable digital inclusive finance index (DIFI) for regression, with a coefficient of 6.319 that is significant at the $5 \%$ level; this illustrates that the higher the DIFI, the more the average number of students per 100,000 junior high schools in the region; that is, the education poverty is alleviated. Based on column (3), column (4) further adds other factors affecting poverty alleviation. The coefficient of the DIFI becomes 7.823, which is still significant at the $5 \%$ level. Columns (5) and (6) take medical poverty (POV3) as the dependent variable, and column (5) only adds the 
TABLE 1: Definition of main variables.

\begin{tabular}{lc}
\hline Variable & Definitions \\
\hline POV1 & Rural per capita disposable income \\
POV2 & Average number of junior high school students per 100000 population \\
POV3 & Number of patients in township hospitals/rural population $* 100$ \\
DIFI & Digital inclusive finance index \\
THEIL & Theil index \\
IE & Total import and export/GDP $* 100$ \\
FE & Fiscal revenue/total DGP $* 100$ \\
UR & Urban population/total population $* 100$ \\
CPI & Consumer price index \\
\hline
\end{tabular}

Table 2: Descriptive statistical analysis.

\begin{tabular}{|c|c|c|c|c|c|c|}
\hline Variable & Sample size & Mean value & Median & Standard deviation & Minimum value & Maximum value \\
\hline POV1 & 248 & 11334.090 & 10478.960 & 4729.642 & 3909.400 & 30374.730 \\
\hline POV2 & 248 & 3309.706 & 3292.000 & 936.138 & 1226.000 & 6146.000 \\
\hline POV3 & 232 & 436.829 & 413.743 & 151.169 & 146.163 & 827.775 \\
\hline DIFI & 248 & 187.175 & 203.935 & 85.079 & 16.220 & 377.730 \\
\hline THEIL & 248 & 5.091 & 4.435 & 2.691 & 2.660 & 21.168 \\
\hline IE & 248 & 26.998 & 14.157 & 30.856 & 1.679 & 154.816 \\
\hline FE & 248 & 28.082 & 22.705 & 21.215 & 11.027 & 137.916 \\
\hline UR & 248 & 56.132 & 54.615 & 13.249 & 22.727 & 89.607 \\
\hline CPI & 248 & 102.500 & 102.100 & 1.288 & 100.600 & 106.300 \\
\hline
\end{tabular}

TABLE 3: Impact of the DIFI on poverty alleviation.

\begin{tabular}{|c|c|c|c|c|c|c|}
\hline \multirow{2}{*}{ Variable } & \multicolumn{2}{|c|}{ POV1 } & \multicolumn{2}{|c|}{ POV2 } & \multicolumn{2}{|c|}{ POV3 } \\
\hline & (1) & (2) & (3) & (4) & (5) & (6) \\
\hline DIFI & $\begin{array}{c}61.359^{* * *} \\
(3.66)\end{array}$ & $\begin{array}{c}50.467^{* * *} \\
(3.70)\end{array}$ & $\begin{array}{c}6.319^{* *} \\
(2.15)\end{array}$ & $\begin{array}{c}7.823^{* *} \\
(2.72)\end{array}$ & $\begin{array}{c}2.117^{* * * *} \\
(3.04)\end{array}$ & $\begin{array}{c}1.979^{* * *} \\
(2.67)\end{array}$ \\
\hline THEIL & & $\begin{array}{c}406.567^{* * *} \\
(5.72)\end{array}$ & & $\begin{array}{c}73.660^{* * * *} \\
(2.94)\end{array}$ & & $\begin{array}{l}3.211 \\
(1.09)\end{array}$ \\
\hline IE & & $\begin{array}{c}-41.880^{* * *} \\
(-5.93)\end{array}$ & & $\begin{array}{l}0.642 \\
(0.32)\end{array}$ & & $\begin{array}{c}-1.785^{* * *} \\
\quad(-3.12)\end{array}$ \\
\hline $\mathrm{FE}$ & & $\begin{array}{l}-8.589 \\
(-0.36)\end{array}$ & & $\begin{array}{l}-2.580 \\
(-0.26)\end{array}$ & & $\begin{array}{l}-1.651 \\
(-1.25)\end{array}$ \\
\hline UR & & $\begin{array}{c}103.430^{* * *} \\
(2.85)\end{array}$ & & $\begin{array}{c}-23.665 \\
(-1.35)\end{array}$ & & $\begin{array}{l}1.322 \\
(0.64)\end{array}$ \\
\hline CPI & & $\begin{array}{c}395.344^{* * *} \\
(3.34)\end{array}$ & & $\begin{array}{c}130.801^{* * *} \\
(4.15)\end{array}$ & & $\begin{array}{l}6.462 \\
(1.01)\end{array}$ \\
\hline Constant & $\begin{array}{c}12734.97^{* * *} \\
(7.64)\end{array}$ & $\begin{array}{c}-28055.880^{* *} \\
(-2.41)\end{array}$ & $\begin{array}{c}1606.206^{* * *} \\
(5.31)\end{array}$ & $\begin{array}{c}-11809.76^{* * *} \\
(-3.41)\end{array}$ & $\begin{array}{c}253.974^{* * *} \\
(11.84)\end{array}$ & $\begin{array}{c}-432.588 \\
(-0.60)\end{array}$ \\
\hline Year fixed effect & & & & & & \\
\hline Province fixed effect & & & & & & \\
\hline Number of samples & 248 & 248 & 248 & 248 & 232 & 232 \\
\hline$F$ & 261.18 & 488.09 & 361.61 & 278.19 & 239.64 & 220.93 \\
\hline$R^{2}$ & 0.979 & 0.987 & 0.955 & 0.960 & 0.961 & 0.964 \\
\hline
\end{tabular}

independent variable digital inclusive finance index (DIFI) for regression, with the coefficient of 2.117 that is significant at the $1 \%$ level. This demonstrates that the higher the DIFI, the higher the diagnosis and treatment rate of township hospitals in this region; that is, the medical poverty is alleviated. Based on column (5), column (6) further adds other factors affecting poverty alleviation. The coefficient of the DIFI drops to 1.979 , but it is still significant at the $1 \%$ level.
3.3.3. Robustness Test. To enhance the reliability of previous empirical results, we tested the robustness from several aspects.

(1) In the benchmark regression of DIF on poverty alleviation, the impact variables of poverty alleviation were added one by one [21]. The direction and significance of the coefficient did not change, and the results were consistent with the existing conclusions. 
(2) Considering the endogenous problem, two-stage least squares (2SLS) estimation was performed, and we used Li Muchen's method for reference [22], multiplied the spherical distance between each province and Zhejiang province with the corresponding digital inclusive finance index, and took the product as an instrumental variable. DIFI is based on the data provided by Ant Group. Although DIF plays a vital role in promoting financial services and financial products, its development is still influenced by the geographical space to some extent. Guo Feng and research from other people revealed that the development level of DIF reduces with the increase in distance from Hangzhou and, hence, slower is the development speed. Although distance affects the income level, education status, and medical conditions of each region, distance does not change with the change in the level of income, education status, and medical conditions. The distance between each province and Zhejiang province meets the two conditions of the instrumental variable; however, the distance variable does not change with time. Thus, the product of distance and the corresponding index was taken as an instrumental variable, and the control variable was added to the regression model, which also controlled the province and year. Table 4 shows the regression results. Using instrumental variables to control endogeneity, the coefficients of the digital inclusive finance index were statistically significant at the $1 \%$ level, and the results were consistent with the conclusions presented.

Instrumental variables pass the test of unrecognizability and weak instrumental variables.

3.4. Transmission Mechanism of DIF. The development of DIF realizes the poverty alleviation path by endorsing economic development. With the growth of digital technology, more residents have the opportunity to enjoy financial services [23]. The reduction in the cost of various services and the introduction of differentiated products
TABLE 4: Impact of DIF on poverty alleviation.

\begin{tabular}{lccc}
\hline Variable & $\begin{array}{c}\text { POV1 } \\
(2)\end{array}$ & $\begin{array}{c}\text { POV2 } \\
(4)\end{array}$ & $\begin{array}{c}\text { POV3 } \\
(6)\end{array}$ \\
\hline \multirow{2}{*}{ DIFI } & $228.349^{* * *}$ & $28.666^{* *}$ & $11.126^{* * *}$ \\
& $(4.46)$ & $(2.41)$ & $(3.51)$ \\
THEIL & $486.967^{* * *}$ & $83.080^{* * *}$ & $10.027^{*}$ \\
& $(4.16)$ & $(2.83)$ & $(1.92)$ \\
IE & -2.538 & 5.252 & -0.835 \\
& $(-0.14)$ & $(1.40)$ & $(-0.92)$ \\
FE & $101.069^{*}$ & 10.270 & 4.179 \\
& $(1.79)$ & $(0.75)$ & $(1.27)$ \\
UR & 82.914 & -26.069 & 1.359 \\
& $(1.48)$ & $(-1.31)$ & $(0.39)$ \\
CPI & $720.340^{* * *}$ & $168.882^{* * *}$ & $19.157^{*}$ \\
& $(3.27)$ & $(4.39)$ & $(1.65)$ \\
Constant & $-86714.71^{* * *}$ & $-21812.69^{* *}$ & -432.588 \\
Year fixed effect & $(-3.11)$ & $(-2.34)$ & $(-0.60)$ \\
Province fixed effect & & Yes & \\
Number of samples & 248 & Yes & \\
\hline
\end{tabular}

help customers to participate in financial activities, select their own financial products and services, enhance transaction efficiency, and provide strong support for economic development. Digital inclusive finance has altered the payment habits of residents, decreased the demand for cash, increased savings, and is advantageous to the accumulation of small savings of residents. The accumulated savings are used for investment, which can further promote economic development and increase regional economic development. Per the "trickle-down effect" theory, with the improvement in the economic development level, the consumption expenditure will also increase. Simultaneously, it will provide more employment opportunities for low-income groups, improve the employment situation of the region, understand the income growth of low-income groups, and eventually eliminate poverty.

Based on the mediating effect test procedure of [24], the path model was set as follows:

$$
\begin{aligned}
\mathrm{POV}_{i, t} & =a_{0}+a_{1} \mathrm{DIFI}_{i, t}+\sum \mathrm{CTRL}_{i, t}+\delta_{i}+\theta_{t}+\varepsilon_{i, t} \text { (path a), } \\
\mathrm{EDL}_{i, t} & =b_{0}+b_{1} \mathrm{DIFI}_{i, t}+\sum \mathrm{CTRL}_{i, t}+\delta_{i}+\theta_{t}+\varepsilon_{i, t} \text { (path b), } \\
\mathrm{POV}_{i, t+1} & =c_{0}+c_{1} \mathrm{DIFI}_{i, t}+c_{2} \mathrm{EDL}_{i, t}+\sum \mathrm{CTRL}_{i, t}+\delta_{i}+\theta_{t}+\varepsilon_{i, t} \text { (path c). }
\end{aligned}
$$

Among them, EDL denotes the intermediary variable, which represents the level of regional economic development, respectively. This study measured using per capita GDP. First, path "a" was used to analyze the impact of the DIFI on poverty alleviation without adding the intermediary variable EDL. If the coefficient $a_{1}$ was significant, it suggested that the total effect of the DIFI on poverty alleviation existed, which could be further analyzed. Second, path b was used to analyze the impact of the DIFI on the intermediary variable EDL. Third, path $\mathrm{c}$ was used to analyze the impact of the DIFI on the intermediary variable EDL on poverty alleviation. If the coefficient $b_{1}$ of path $\mathrm{b}$ and the coefficient $c_{2}$ of path $\mathrm{c}$ were significant, it implied that the mediating effect existed. If the coefficient $c_{1}$ was nonsignificant, it implied that the mediator played a complete mediating role. If the 
TABLE 5: Impact of various financial services of digital inclusive finance on poverty alleviation: transmission mechanism test.

\begin{tabular}{|c|c|c|c|}
\hline Path a (without mediators) & $\begin{array}{l}\text { POV1 } \\
(1)\end{array}$ & $\begin{array}{l}\text { POV2 } \\
(2)\end{array}$ & $\begin{array}{l}\text { POV3 } \\
(3)\end{array}$ \\
\hline DIFI & $\begin{array}{l}50.467^{* * *} \\
(6.03)\end{array}$ & $\begin{array}{c}7.823^{* * *} \\
(2.70)\end{array}$ & $\begin{array}{c}1.979^{* * *} \\
(3.92)\end{array}$ \\
\hline Control variable & Control & Control & Control \\
\hline Year fixed effect & Control & Control & Control \\
\hline Province fixed effect & Control & Control & Control \\
\hline Number of samples & 248 & 248 & 232 \\
\hline$R^{2}$ & 0.987 & 0.960 & 0.964 \\
\hline Path b (mediator) & $\begin{array}{l}\text { EDL } \\
(4)\end{array}$ & $\begin{array}{l}\mathrm{EDL} \\
(5)\end{array}$ & $\begin{array}{c}\text { EDL } \\
(6)\end{array}$ \\
\hline DIFI & $\begin{array}{l}324.893^{* * *} \\
\quad(7.03)\end{array}$ & $\begin{array}{l}324.893^{* * *} \\
\quad(7.03)\end{array}$ & $\begin{array}{c}324.893^{* * *} \\
(7.03)\end{array}$ \\
\hline Control variable & Control & Control & Control \\
\hline Year fixed effect & Control & Control & Control \\
\hline Province fixed effect & Control & Control & Control \\
\hline Number of samples & 248 & 248 & 248 \\
\hline$R^{2}$ & 0.986 & 0.986 & 0.986 \\
\hline $\begin{array}{l}\text { Path c (including } \\
\text { mediators) }\end{array}$ & $\begin{array}{l}\text { POV1 } \\
(7)\end{array}$ & $\begin{array}{l}\text { POV2 } \\
(8)\end{array}$ & $\begin{array}{l}\text { POV3 } \\
\text { (9) }\end{array}$ \\
\hline DIFI & $\begin{array}{c}16.693^{* *} \\
(2.18)\end{array}$ & $\begin{array}{l}4.771 \\
(1.49)\end{array}$ & $\begin{array}{l}0.804 \\
(1.50)\end{array}$ \\
\hline EDL & $\begin{array}{l}0.104^{* * *} \\
(9.99)\end{array}$ & $\begin{array}{c}0.009^{* *} \\
(2.16)\end{array}$ & $\begin{array}{c}0.004^{* * *} \\
(4.81)\end{array}$ \\
\hline Control variable & Control & Control & Control \\
\hline Year fixed effect & Control & Control & Control \\
\hline Province fixed effect & Control & Control & Control \\
\hline Number of samples & 248 & 248 & 232 \\
\hline$R^{2}$ & 0.991 & 0.961 & 0.968 \\
\hline$P$ value of the Sobel test & $\leq 0.001$ & 0.039 & $\leq 0.001$ \\
\hline
\end{tabular}

coefficient $c_{1}$ was significant, it suggested that the mediator played a partial mediating role. If at least one of the coefficient $b_{1}$ of path $\mathrm{b}$ and the coefficient $c_{2}$ of path $\mathrm{c}$ was not significant, Sobel test was conducted to determine whether a mediating effect existed.

Table 5 presents the results of the intermediary test of the economic development level. Path a test showed that the DIFI coefficients were 50.467, 7.823, and 1.979 , respectively, which were statistically significant at the $1 \%$ level. Path $b$ test showed that digital inclusive finance was significantly positively correlated with economic development at the $1 \%$ statistical level. Path $\mathrm{c}$ test demonstrated that, after adding the mediating factor EDL, the coefficients of mediating factor EDL were significant at the 1\% statistical level and also passed the Sobel test. For the three dimensions of poverty alleviation, DIFI's regression coefficient values declined. In addition, the impact of the digital inclusive finance index on income poverty alleviation was only significant at the $5 \%$ statistical level, while the impact on education poverty alleviation and medical poverty alleviation was not significant, suggesting that the level of economic development played a partial intermediary role in the impact of DIF on income poverty alleviation, and it has a complete mediating effect in the impact of digital inclusive finance on education poverty alleviation and medical poverty alleviation.

\section{Additional Analysis}

4.1. The Impact of Various Dimensions of Digital Inclusive Finance on Poverty Alleviation. Digital inclusive finance index includes three dimensions-coverage breadth, use depth, and digitization degree [25]. The coverage breadth of DIF is reflected in the coverage of financial services, including the number and scope of users who conduct financial transactions through digital means such as internet and mobile terminals. The wider coverage of digital inclusive finance illustrates that more groups benefit from digital finance, alleviates financial exclusion, and gives the groups, who cannot enjoy financial services owing to geographical restrictions, the opportunity to avail appropriate financial services [26]. Specifically, in terms of coverage areas, traditional financial services need to improve coverage by setting up institutional outlets, but the high cost of institutional outlets makes it difficult for traditional financial services to penetrate into economically backward areas [27]. The cross-border integration of digital technology and financial services overcomes this disadvantage. Even without bank outlets, ATM, and other hardware facilities in some areas, customers can still obtain the required financial services through computers, mobile phones, and other terminal devices. Compared with the situation that traditional financial institutions distribute their main resources in densely populated and commercial areas, digital finance makes financial services more direct and customer coverage wider. The product innovation of digital finance reduces the customer access threshold and makes the trend of popularization of financial services more obvious. The use depth of DIF is reflected in the types of financial services, including payment services, monetary fund services, credit services, insurance services, and investment services. Deeper the use of DIF, the more diversified the financial activities of digital financial service users through digital means. The digital degree of DIF depicts the influencing factors of users' use of digital financial services, including the degree of mobility, degree of affordability, degree of credit, and degree of convenience. The higher the digital degree of DIF, the lower the cost and higher the convenience of digital financial services.

We further tested the impact of the coverage, depth, and digitization degree of DIF on poverty alleviation. Table 6 shows the specific results. The results explain that the coverage breadth of DIF exerts no significant impact on the alleviation of income poverty and education poverty; however, the regression coefficient for the alleviation of medical poverty is 2.011 , which is significantly positive at the $1 \%$ statistical level, suggesting that the higher the coverage breadth of DIF, the higher the diagnosis and treatment rate of township health centers, which affects the alleviation of medical poverty. The regression coefficients of the use depth of DIF to income poverty and education poverty were 18.625 and 3.750 , respectively, which were significantly positive at the $1 \%$ statistical level, suggesting that the deeper the use depth of DIF, the greater the impact on the alleviation of income poverty and education poverty, while the impact on the alleviation of medical poverty was not significant. The regression 
TABLE 6: Impact of coverage breadth, use depth, and digitization degree of DIF on poverty alleviation.

\begin{tabular}{|c|c|c|c|c|c|c|c|c|c|}
\hline \multirow{2}{*}{ Variable } & \multicolumn{3}{|c|}{ POV1 } & \multicolumn{3}{|c|}{ POV2 } & \multicolumn{3}{|c|}{ POV3 } \\
\hline & (1) & (2) & (3) & $(4)$ & (5) & $(6)$ & (7) & $(8)$ & (9) \\
\hline Breadth & $\begin{array}{l}-8.640 \\
(-0.72)\end{array}$ & & & $\begin{array}{l}-4.240 \\
(-1.01)\end{array}$ & & & $\begin{array}{c}2.011^{* * *} \\
(3.42)\end{array}$ & & \\
\hline Depth & & $\begin{array}{l}18.625^{* * *} \\
(2.59)\end{array}$ & & & $\begin{array}{c}3.750^{* * *} \\
(2.65)\end{array}$ & & & $\begin{array}{l}0.549 \\
(1.43)\end{array}$ & \\
\hline Digit & & & $\begin{array}{l}16.801^{* * *} \\
(4.49)\end{array}$ & & & $\begin{array}{c}2.542^{* * *} \\
(2.95)\end{array}$ & & & $\begin{array}{l}0.370^{*} \\
(1.77)\end{array}$ \\
\hline THEIL & $\begin{array}{l}365.257^{* * *} \\
(5.20)\end{array}$ & $\begin{array}{l}389.543^{* * *} \\
(5.59)\end{array}$ & $\begin{array}{l}301.995^{* * *} \\
\quad(4.80)\end{array}$ & $\begin{array}{l}61.044^{* * *} \\
(2.63)\end{array}$ & $\begin{array}{l}71.289^{* * *} \\
(2.97)\end{array}$ & $\begin{array}{l}57.753^{* *} \\
(2.37)\end{array}$ & $\begin{array}{c}6.006^{*} \\
(1.88)\end{array}$ & $\begin{array}{l}2.101 \\
(0.67)\end{array}$ & $\begin{array}{l}0.383 \\
(0.12)\end{array}$ \\
\hline IE & $\begin{array}{c}53.59^{* * *} \\
(-6.88)\end{array}$ & $\begin{array}{c}43.402^{* * *} \\
(-5.89)\end{array}$ & $\begin{array}{c}-49.662^{* * *} \\
(-7.57)\end{array}$ & $\begin{array}{l}-1.360 \\
(-0.64)\end{array}$ & $\begin{array}{c}0.853 \\
(0.040)\end{array}$ & $\begin{array}{l}-0.577 \\
(-0.28)\end{array}$ & $\begin{array}{c}-1.919^{* * *} \\
(-3.23)\end{array}$ & $\begin{array}{c}-1.721^{* * *} \\
(-2.82)\end{array}$ & $\begin{array}{c}-2.131^{* * *} \\
(-3.58)\end{array}$ \\
\hline $\mathrm{FE}$ & $\begin{array}{r}-42.076^{*} \\
(-1.87)\end{array}$ & $\begin{array}{c}-31.479 \\
(-1.47)\end{array}$ & $\begin{array}{l}-5.057 \\
(-0.22)\end{array}$ & $\begin{array}{l}-8.568 \\
(-0.85)\end{array}$ & $\begin{array}{l}-5.747 \\
(-0.58)\end{array}$ & $\begin{array}{l}-2.160 \\
(-0.22)\end{array}$ & $\begin{array}{c}-2.397^{*} \\
(-1.94)\end{array}$ & $\begin{array}{c}-2.666^{* *} \\
(-2.09)\end{array}$ & $\begin{array}{l}-2.084 \\
(-1.53)\end{array}$ \\
\hline UR & $\begin{array}{c}104.369^{* *} \\
(2.37)\end{array}$ & $\begin{array}{l}92.853^{* *} \\
(2.41)\end{array}$ & $\begin{array}{l}92.876^{* * *} \\
(2.87)\end{array}$ & $\begin{array}{c}-25.159 \\
(-1.41)\end{array}$ & $\begin{array}{c}-26.064 \\
(-1.50)\end{array}$ & $\begin{array}{c}-25.240 \\
(-1.45)\end{array}$ & $\begin{array}{l}2.510 \\
(1.13)\end{array}$ & $\begin{array}{l}1.050 \\
(0.52)\end{array}$ & $\begin{array}{l}0.918 \\
(0.46)\end{array}$ \\
\hline CPI & $\begin{array}{c}289.168^{* *} \\
(2.14)\end{array}$ & $\begin{array}{c}396.017^{* * *} \\
(3.19)\end{array}$ & $\begin{array}{c}249.008^{* *} \\
(2.16)\end{array}$ & $\begin{array}{c}109.651^{* * *} \\
(3.48)\end{array}$ & $\begin{array}{l}135.208^{* * *} \\
(2.65)\end{array}$ & $\begin{array}{c}108.317^{* * *} \\
(3.68)\end{array}$ & $\begin{array}{l}7.723 \\
(1.25)\end{array}$ & $\begin{array}{l}6.281 \\
(0.99)\end{array}$ & $\begin{array}{l}1.278 \\
(0.22)\end{array}$ \\
\hline Constant & $\begin{array}{c}8699.576 \\
(-0.58)\end{array}$ & $\begin{array}{c}24432.14^{*} \\
(-1.81)\end{array}$ & $\begin{array}{c}-6546.353 \\
(-0.52)\end{array}$ & $\begin{array}{c}-7897.916^{* *} \\
(-2.23)\end{array}$ & $\begin{array}{c}-11851.1^{* * *} \\
(-3.34)\end{array}$ & $\begin{array}{c}-8493.508^{* * *} \\
(-2.72)\end{array}$ & $\begin{array}{c}-589.443 \\
(-0.84)\end{array}$ & $\begin{array}{c}-330.177 \\
(-0.47)\end{array}$ & $\begin{array}{c}208.435 \\
(0.33)\end{array}$ \\
\hline $\begin{array}{l}\text { Year fixed effect } \\
\text { Province fixed effect }\end{array}$ & & & & & $\begin{array}{l}\text { Yes } \\
\text { Yes }\end{array}$ & & & & \\
\hline Number of samples & 248 & 248 & 248 & 248 & 248 & 248 & 232 & 232 & 232 \\
\hline$F$ & 664.58 & 455.27 & 494.23 & 284.45 & 312.09 & 252.82 & 198.91 & 174.00 & 163.28 \\
\hline$R^{2}$ & 0.985 & 0.986 & 0.988 & 0.959 & 0.960 & 0.961 & 0.963 & 0.962 & 0.962 \\
\hline
\end{tabular}

${ }^{*},{ }^{* *}$, and ${ }^{* * *}$ indicate $10 \%, 5 \%$, and $1 \%$ significance levels.

coefficients of digital inclusive finance on income poverty and education poverty were 16.801 and 2.542 , respectively, which were significantly positive at the $1 \%$ statistical level, suggesting that the deeper the digital degree of digital inclusive finance, the greater the impact on alleviating income poverty and education poverty, while the regression coefficient of medical poverty was 0.370 , which was significantly positive at the $10 \%$ statistical level, suggesting that the digital inclusive finance positively affects alleviating income poverty and education poverty, while digital inclusive finance positively affects the alleviation of medical poverty.

4.2. The Impact of Various Financial Services of Digital Inclusive Finance on Poverty Alleviation. Currently, the types of financial services covered by China's digital inclusive finance primarily include payment business, insurance business, monetary fund business, investment business, and credit business [28]. Different types of service industries reflect the development of the use depth of digital inclusive finance business, and different depths exert different impacts on poverty alleviation.

This study further tested the impact of different types of financial services of digital inclusive finance on poverty alleviation. Tables 7-9 show specific results. The results indicate that payment business and insurance business have played a role in alleviating income, education, and medical poverty; monetary fund business affects alleviating education poverty, investment business affects alleviating income poverty and medical poverty, while credit business has no significant impact on alleviating poverty.
4.3. Regional Heterogeneity Test of Digital Inclusive Finance. There are great differences in the level of economic and social development in different regions of China. The economic development in the eastern region is relatively high, while economic development in the western region is relatively low [29]. Thus, per the division standard of the three zones of the International Bureau of Statistics, the sample was divided into three parts - the eastern part, the central part, and the western part. Table 10 shows the test results of regional heterogeneity of DIF. From the perspective of the alleviation effect of DIF on income poverty, the coefficients of the DIFI were 88.634 and 34.954 in the eastern and central regions, respectively, and were significant at the $1 \%$ statistical level, but in the western region, it is not significant, suggesting that the alleviation effect of DIF on income poverty was most obvious in the eastern region, whereas the impact on the central region was marginally decreased, with no significant effect on the western region. From the perspective of the alleviation effect of DIF on education poverty, the coefficient of the DIFI was 88.634 in the east, which was significant at the $1 \%$ statistical level, but in the central and western regions, it is not significant, suggesting that the alleviation effect of DIF on education poverty was obvious in the east, with no significant effect on the central and western regions. From the perspective of the alleviation effect of DIF on medical poverty, the coefficients of the digital inclusive finance index were 4.479 and 3.389 in the eastern and central regions, respectively, which were significant at the $1 \%$ statistical level, but not significant in the western region, suggesting that the alleviation effect of DIF on medical 
TABLE 7: Impact of various financial services of digital inclusive finance on poverty alleviation: income poverty.

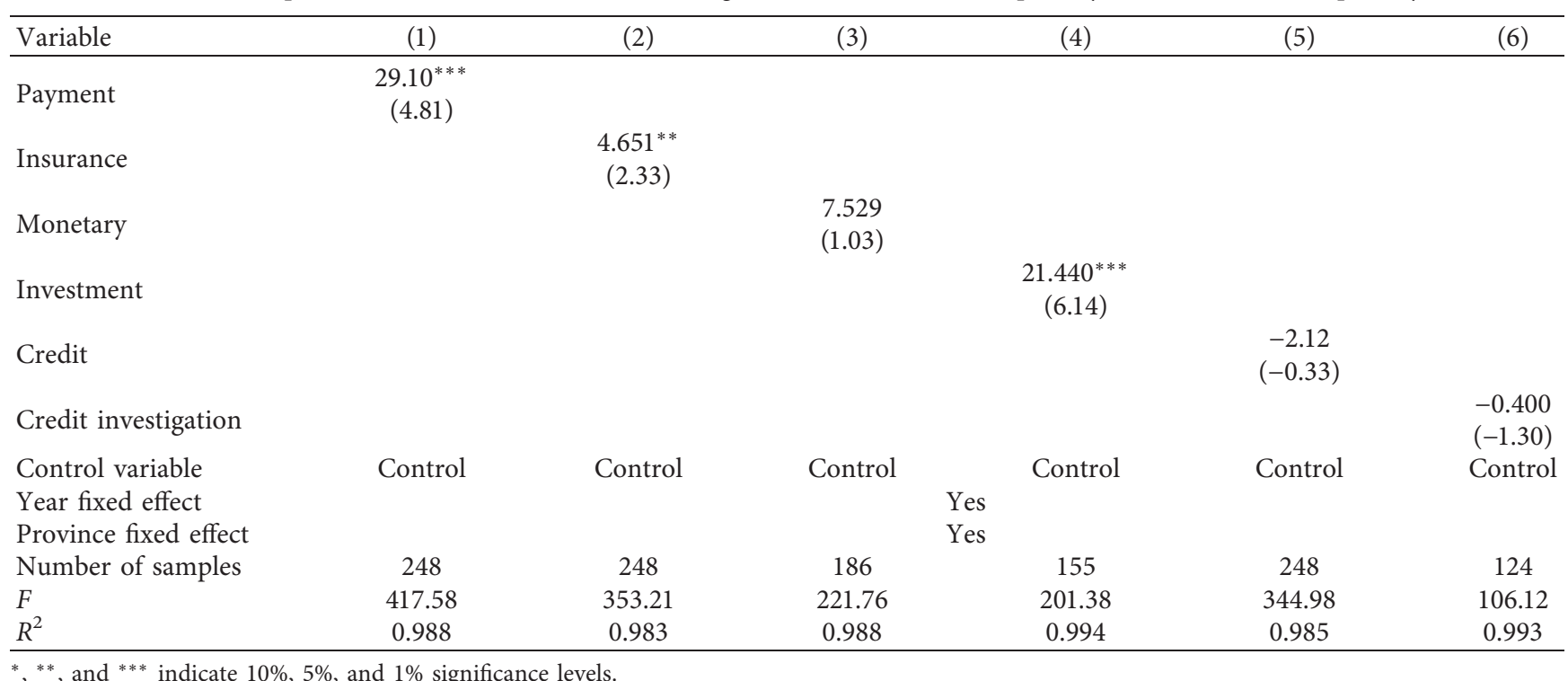

TABLE 8: Impact of various financial services of digital inclusive finance on poverty alleviation: education poverty.

\begin{tabular}{|c|c|c|c|c|c|c|c|}
\hline Variable & (1) & (2) & (3) & & (4) & (5) & $(6)$ \\
\hline Payment & $\begin{array}{c}5.25^{* * * *} \\
(4.20)\end{array}$ & & & & & & \\
\hline Insurance & & $\begin{array}{c}1.157^{* * *} \\
(2.85)\end{array}$ & & & & & \\
\hline Monetary & & & $\begin{array}{c}7.251^{* * *} \\
(4.62)\end{array}$ & & & & \\
\hline Investment & & & & & $\begin{array}{l}0.997 \\
(0.90)\end{array}$ & & \\
\hline Credit & & & & & & $\begin{array}{l}-0.320 \\
(-0.16)\end{array}$ & \\
\hline Credit investigation & & & & & & & $\begin{array}{l}0.429 \\
(1.09)\end{array}$ \\
\hline Control variable & & & & Yes & & & \\
\hline Year fixed effect & & & & Yes & & & \\
\hline Province fixed effect & & & & Yes & & & \\
\hline Number of samples & 248 & 248 & 186 & & 155 & 248 & 124 \\
\hline & 19.21 & 16.55 & 8.43 & & 5.40 & 16.04 & 5.01 \\
\hline$R^{2}$ & 0.962 & 0.960 & 0.981 & & 0.985 & 0.959 & 0.990 \\
\hline
\end{tabular}

TABLE 9: Impact of various financial services of digital inclusive finance on poverty alleviation: medical poverty.

\begin{tabular}{|c|c|c|c|c|c|c|c|c|}
\hline Variable & (1) & (2) & (3) & (4) & (5) & (6) & & \\
\hline Payment & $0.855^{* *}$ & & $(2.52)$ & & & & & \\
\hline Insurance & & $0.219^{* *}$ & & $(2.16)$ & & & & \\
\hline Monetary & & & 0.088 & & $(0.28)$ & & & \\
\hline Investment & & & & $0.559^{* *}$ & & $(2.09)$ & & \\
\hline Credit & & & & & -0.400 & & $(-1.30)$ & \\
\hline $\begin{array}{l}\text { Credit investigation } \\
\text { Control variable }\end{array}$ & & & Ye & & & -0.007 & & $(-0.06)$ \\
\hline
\end{tabular}


TABle 9: Continued.

\begin{tabular}{|c|c|c|c|c|c|c|}
\hline Variable & (1) & (2) & (3) & $(4)$ & (5) & (6) \\
\hline Year fixed effect & & & $\mathrm{Ye}$ & & & \\
\hline Province fixed effect & & & $\mathrm{Ye}$ & & & \\
\hline Number of samples & 232 & 232 & 174 & 145 & 232 & 124 \\
\hline$F$ & 11.81 & 13.91 & 4.81 & 5.43 & 12.54 & 3.72 \\
\hline$R^{2}$ & 0.964 & 0.963 & 0.976 & 0.985 & 0.961 & 0.982 \\
\hline
\end{tabular}

${ }^{*},{ }^{* *}$, and ${ }^{* * *}$ indicate $10 \%, 5 \%$, and $1 \%$ significance levels.

TABLE 10: Regional heterogeneity test of digital inclusive finance.

\begin{tabular}{|c|c|c|c|c|c|c|c|c|c|}
\hline & & POV1 & & & POV2 & & & POV3 & \\
\hline Variable & $\begin{array}{c}\text { East } \\
(1)\end{array}$ & $\begin{array}{l}\text { Central } \\
\text { section } \\
(2)\end{array}$ & $\begin{array}{c}\text { West } \\
(3)\end{array}$ & $\begin{array}{c}\text { East } \\
(4)\end{array}$ & $\begin{array}{l}\text { Central } \\
\text { section } \\
(5)\end{array}$ & $\begin{array}{c}\text { West } \\
(6)\end{array}$ & $\begin{array}{c}\text { East } \\
(7)\end{array}$ & $\begin{array}{l}\text { Central } \\
\text { section } \\
(8)\end{array}$ & $\begin{array}{c}\text { West } \\
(9)\end{array}$ \\
\hline DIFI & $\begin{array}{c}88.634^{* * *} \\
(3.55)\end{array}$ & $\begin{array}{c}34.954^{* * *} \\
(3.20)\end{array}$ & $\begin{array}{c}12.140 \\
(1.51)\end{array}$ & $\begin{array}{c}2.133^{* *} \\
(2.15)\end{array}$ & $\begin{array}{l}0.417 \\
(0.04)\end{array}$ & $\begin{array}{l}0.977 \\
(0.23)\end{array}$ & $\begin{array}{c}4.479^{* * *} \\
(2.80)\end{array}$ & $\begin{array}{c}3.389^{* * *} \\
(3.25)\end{array}$ & $\begin{array}{l}-0.233 \\
(-0.38)\end{array}$ \\
\hline THEIL & $\begin{array}{c}1755.41 \\
* * * \\
(3.16)\end{array}$ & $\begin{array}{c}178.769 \\
(0.52)\end{array}$ & $\begin{array}{c}101.900^{* *} \\
(2.02)\end{array}$ & $\begin{array}{c}-229.363 \\
(-1.28)\end{array}$ & $\begin{array}{c}-258.627 \\
(-1.07)\end{array}$ & $\begin{array}{l}41.259 \\
(1.36)\end{array}$ & $\begin{array}{l}29.129 \\
(0.75)\end{array}$ & $\begin{array}{c}-23.618 \\
(-0.96)\end{array}$ & $\begin{array}{c}-7.139^{*} \\
(-1.94)\end{array}$ \\
\hline IE & $\begin{array}{l}-6.892 \\
(-0.55)\end{array}$ & $\begin{array}{c}68.211^{*} \\
(1.88)\end{array}$ & $\begin{array}{l}-5.332 \\
(-0.56)\end{array}$ & $\begin{array}{c}7.816^{* * *} \\
(2.78)\end{array}$ & $\begin{array}{c}-25.590 \\
(-1.08)\end{array}$ & $\begin{array}{l}-2.733 \\
(-0.55)\end{array}$ & $\begin{array}{l}1.613 \\
(1.53)\end{array}$ & $\begin{array}{c}6.569^{* * *} \\
(2.73)\end{array}$ & $\begin{array}{l}-0.954 \\
(-1.19)\end{array}$ \\
\hline $\mathrm{FE}$ & $\begin{array}{c}209.854^{* *} \\
(2.60)\end{array}$ & $\begin{array}{r}-16.837 \\
(-0.31)\end{array}$ & $\begin{array}{l}-9.237 \\
(-0.51)\end{array}$ & $\begin{array}{l}5.513 \\
(0.31)\end{array}$ & $\begin{array}{l}-42.219 \\
(-0.89)\end{array}$ & $\begin{array}{l}-0.690 \\
(-0.06)\end{array}$ & $\begin{array}{l}0.487 \\
(0.10)\end{array}$ & $\begin{array}{c}4.742^{* *} \\
(1.32)\end{array}$ & $\begin{array}{l}-1.425 \\
(-1.23)\end{array}$ \\
\hline UR & $\begin{array}{c}163.098^{* *} \\
(2.38)\end{array}$ & $\begin{array}{c}-50.573 \\
(-1.34)\end{array}$ & $\begin{array}{c}37.523 \\
(1.05)\end{array}$ & $\begin{array}{l}-6.198 \\
(-0.36)\end{array}$ & $\begin{array}{r}26.581 \\
(0.78)\end{array}$ & $\begin{array}{c}-47.367^{* *} \\
(-2.29)\end{array}$ & $\begin{array}{c}1.19 \\
(0.25)\end{array}$ & $\begin{array}{l}-0.379 \\
(-0.16)\end{array}$ & $\begin{array}{l}2.963 \\
(0.94)\end{array}$ \\
\hline CPI & $\begin{array}{c}236.027 \\
(1.05)\end{array}$ & $\begin{array}{c}322.331^{* *} \\
(2.30)\end{array}$ & $\begin{array}{l}15.814 \\
(0.23)\end{array}$ & $\begin{array}{r}22.940 \\
(0.37)\end{array}$ & $\begin{array}{c}293.12^{* * * *} \\
(3.28)\end{array}$ & $\begin{array}{l}45.147 \\
(0.95)\end{array}$ & $\begin{array}{l}9.377 \\
(0.62)\end{array}$ & $\begin{array}{c}16.932^{* *} \\
(2.03)\end{array}$ & $\begin{array}{c}-14.542^{* *} \\
(-2.35)\end{array}$ \\
\hline Constant & $\begin{array}{c}-37912.99 \\
(-1.53)\end{array}$ & $\begin{array}{c}-26949.51^{*} \\
(-1.76)\end{array}$ & $\begin{array}{c}1010.995 \\
(0.13)\end{array}$ & $\begin{array}{c}380.371 \\
(0.06)\end{array}$ & $\begin{array}{c}-26054.78^{* *} \\
(-2.66)\end{array}$ & $\begin{array}{c}1613.986 \\
(0.31)\end{array}$ & $\begin{array}{c}-1029.237 \\
(-0.59)\end{array}$ & $\begin{array}{c}-1561.111^{*} \\
(-0.47)\end{array}$ & $\begin{array}{c}1832.745^{* * *} \\
(2.84)\end{array}$ \\
\hline $\begin{array}{l}\text { Year fixed effect } \\
\text { Province fixed } \\
\text { effect }\end{array}$ & & & & & $\begin{array}{l}\text { Yes } \\
\text { Yes }\end{array}$ & & & & \\
\hline $\begin{array}{l}\text { Number of } \\
\text { samples }\end{array}$ & 88 & 64 & 96 & 88 & 64 & 96 & 72 & 64 & 96 \\
\hline $\begin{array}{l}F \\
R^{2}\end{array}$ & $\begin{array}{c}164.14 \\
0.987\end{array}$ & $\begin{array}{r}811.80 \\
0.994\end{array}$ & $\begin{array}{c}358.28 \\
0.990\end{array}$ & $\begin{array}{c}2.76 \\
0.960\end{array}$ & $\begin{array}{c}9.14 \\
0.950\end{array}$ & $\begin{array}{l}15.31 \\
0.959\end{array}$ & $\begin{array}{c}9.45 \\
0.938\end{array}$ & $\begin{array}{l}23.82 \\
0.989\end{array}$ & $\begin{array}{r}6.78 \\
0.951\end{array}$ \\
\hline
\end{tabular}

${ }^{*},{ }^{* *}$, and ${ }^{* * *}$ indicate $10 \%, 5 \%$, and $1 \%$ significance levels.

poverty should be the most notable in the eastern region, with a marginal decline in the central region and no significant effect on the western region. Generally speaking, the groups with a higher education level are more eager and need to use digital information means to obtain more useful information and have corresponding information retrieval ability, information acquisition ability, and absorption and digestion ability, while the groups with a lower education level will appear poorer at the information level, resulting in the phenomenon of digital divide. The digital divide also leads to the difference of residents' utilization of digital inclusive finance in different regions.

\section{Conclusions}

The findings of this study are as follows: (1) digital inclusive finance exerts a poverty reduction effect in three dimensions of income, education, and healthcare. (2) The level of economic development plays a partial mediating role in the impact of DIF on income poverty alleviation, while it plays a complete mediating role in the impact of DIF on education poverty alleviation and medical poverty alleviation. (3) The coverage breadth of DIF exerts a significant impact on the alleviation of medical poverty, the use depth of DIF exerts a significant impact on the alleviation of income poverty and education poverty, and the digital degree of DIF exerts an impact on the alleviation of poverty in three dimensions. (4) The types of financial services also exert different effects on poverty alleviation. Generally, payment business and insurance business exert significant effects on the three dimensions of poverty alleviation. (5) The poverty reduction effect of DIF is the most notable in the eastern region, followed by the central region, but not significant in the western region.

Digital inclusive finance plays an evident role in poverty alleviation; however, from the perspective of use depth, the impact of credit business and investment business on poverty alleviation is not obvious. In future, we can appropriately increase the development of such financial 
business to alleviate the financial constraints of low-income groups. The economic development level of the western region and the construction of network infrastructure are relatively backward, which also affects the application of digital inclusive finance. In future, we can accelerate the construction and upgrading of communication network hardware in remote areas such that the residents can enjoy appropriate financial services and promote the expansion of DIF in the western region.

\section{Data Availability}

Data sharing is not applicable to this article as no datasets were generated or analyzed during the current study.

\section{Conflicts of Interest}

The authors declare no conflicts of interest.

\section{Acknowledgments}

This work was supported by Science and Technology Research Project of Chongqing Education Commission of China (KJQN201903304).

\section{References}

[1] A. Leyshon and N. Thrift, "Geographies of financial exclusion: financial abandonment in Britain and the United States," Transactions of the Institute of British Geographers, vol. 20, no. 3, pp. 312-341, 1995.

[2] R. Mohan, "Economic growth, financial deepening and financial inclusion," in Proceedings of the Annual Bankers' Conference 2006, Hyderabad, November 2006.

[3] M. Sarma, Index of Financial Inclusion, ICRIER Working Paper, Washington, DC, USA, 2008.

[4] Rangarajan Committee, Report of the Committee on Financial Inclusion, Government of India, South Asia, 2008.

[5] P. Honohan, "Cross-country variation in household access to financial services," Journal of Banking \& Finance, vol. 32, no. 11, pp. 2493-2500, 2008.

[6] G. Amidžić, A. Massara, and A. Mialou, "Assessing countries' financial inclusion standing-a new composite index," Journal of Banking and Financial Economics, vol. 2, no. 8, 2017.

[7] A. Hannig and S. Jansen, Financial Inclusion and Financial Stability: Current Policy Issues, Working Paper, Washington, DC, USA, 2010.

[8] L. Brune, X. Giné, J. Goldberg, and D. Yang, "Commitments to save: a field experiment in rural Malawi," Working Paper, Washington, DC, USA, 2011.

[9] T. Beck, A. Demirgüç-Kunt, and R. Levine, "Finance, inequality and the poor," Journal of Economic Growth, vol. 12, no. 1, pp. 27-49, 2007.

[10] A. Demirgüç-Kunt and R. Levine, "Finance and inequality: theory and evidence," Annual Review of Financial Economics, vol. 1, no. 1, pp. 287-318, 2009.

[11] F. Allen, E. Carletti, R. Cull, J. Qian, L. Senbet, and P. Valenzuela, 2013.

[12] A. Alvarez de la Campa, Increasing Access to Credit through Reforming Secured Transactions in the MENA Region, Working Paper, Washington, DC, USA, 2010.
[13] D. Pearce, Financial Inclusion in the Middle East and North Africa: Analysis and Roadmap Recommendations, Working Paper, Washington, DC, USA, 2011.

[14] N. Emara and M. Mohieldin, "Financial inclusion and extreme poverty in the MENA region: a gap analysis approach," Review of Economics and Political Science, vol. 6, 2020.

[15] M. Andrianaivo and K. Kpodar, ICT, Financial Inclusion, and Growth: Evidence from African Countries, Working Paper, Washington, DC, USA, 2011.

[16] L. Klapper, M. El-Zoghbi, and J. Hess, Achieving the Sustainable Development Goals: The Role of Financial Inclusion, Working Paper,2016, Washington, DC, USA, 2016.

[17] T. Beck, H. Pamuk, R. Ramrattan, and B. R. Uras, "Payment instruments, finance and development," Journal of Development Economics, vol. 133, no. 7, pp. 162-186, 2018.

[18] H. Wang, X.-M. Zhang, G. Tomiyoshi et al., "Association of serum levels of antibodies against MMP1, CBX1, and CBX5 with transient ischemic attack and cerebral infarction," Oncotarget, vol. 9, no. 5, pp. 5600-5613, 2017.

[19] Digital Finance at Peking University and Ant Financial Services Group, "The peking university digital financial inclusion index of China, 2011-2018," Institute of Digital Finance Peking University, Index Report, Beijing, China, 2019.

[20] Q. Gong and X. Cheng, "Digital financial inclusion, rural poverty and economic growth," Gansu Social Sciences, vol. 6, pp. 139-145, 2018.

[21] H. Qian, Li Zheng, and X. De-ping, "Poverty reduction effect of digital inclusive finance and its transmission mechanism," Reformation, vol. 11, pp. 90-101, 2019.

[22] M. Li, S. Feng, and X. Xing, "Heterogeneity effects of digital inclusive finance on urban-rural income gap," Journal of Nanjing Agricultural University, vol. 20, no. 3, pp. 132-145, 2020.

[23] J. Li and X. Han, "The effect of financial inclusion on income distribution and poverty alleviation:policy framework selection for efficiency and equity," Journal of Financial Research, vol. 3, pp. 129-148, 2019.

[24] Z. L. Wen, L. Zhang, J. Hou, and H. Liu, "Testing and application of the mediating effects," Acta Psychologica Sinica, vol. 36, no. 5, pp. 614-620, 2004.

[25] J. Liu and C. Liu, "Rural poverty alleviation effect of digital inclusive finance: effects and mechanisms," Collected Essays on Finance and Economics, vol. 1, pp. 43-53, 2020.

[26] H. Luo and J. Luo, "Research on the influences of inclusive finance on rural poverty alleviation from a multidimensional perspective," Contemporary Economic Management, vol. 41, no. 3, pp. 80-88, 2019.

[27] H. Shao and K. Wang, "Poverty reduction effect and the mechanism of action in inclusive finance: empirical analysis based on cross-national panel data," Financial Economics Research, vol. 32, no. 6, pp. 65-74, 2017.

[28] W. Yang, L. Su, and M. Wang, "Digital financial inclusion and income of urban and rural residents: based on the intermediary effec of economic growth and entrepreneurial behavior," Journal of Shanghai University of Finance and Economics, vol. 22, no. 4, pp. 83-94, 2020.

[29] X. Zheng and Y. Zhu, "Inclusive Finance, Economic opportunity and poverty reduction," World Economic Papers, vol. 1, pp. 101-120, 2019. 